\title{
Perception of professionals of the family health strategy on diseases transmitted by water and food
}

\author{
Percepção de profisssionais da estratégia em saúde da família sobre doenças transmitidas por água e \\ alimentos
}

Percepción de los profesionales de la estrategia de salud familiar sobre las enfermedades transmitidas por agua y alimentos

Recebido: 14/12/2021 | Revisado: 17/12/2021 | Aceito: 18/01/2022 | Publicado: 20/01/2022

\author{
Bianca Conrad Bohm \\ ORCID: https://orcid.org/0000-0002-5050-7497 \\ Universidade Federal de Pelotas, Brazil \\ E-mail: biankabohm@ hotmail.com \\ Caroline da Silveira Rockenbach \\ ORCID: https://orcid.org/0000-0002-2948-7954 \\ Universidade Federal de Pelotas, Brazil \\ E-mail: carol.rockembach@hotmail.com \\ Vitor Campos Assumpção de Amarante \\ ORCID: https://orcid.org/0000-0002-0576-0442 \\ Universidade Federal de Pelotas, Brazil \\ E-mail: vitor_amarante@ hotmail.com \\ Laura Aparecida Martins de Moraes \\ ORCID: https://orcid.org/0000-0003-3672-8020 \\ Universidade Federal de Pelotas, Brazil \\ E-mail: laura_m_moraes@outlook.com \\ Christieli Prestes Osmari \\ ORCID: https://orcid.org/0000-0003-1605-5674 \\ Médica Veterinária, Brazil \\ E-mail: ch.prestes@gmail.com \\ Roberta Silva Silveira da Mota \\ ORCID: https://orcid.org/0000-0002-5918-3011 \\ CCZ Prefeitura Municipal de Pelotas, Brazil \\ E-mail: robertassmota@gmail.com \\ Fábio Raphael Pascoti Bruhn \\ ORCID: https://orcid.org/0000-0002-4191-965X \\ Universidade Federal de Pelotas, Brazil \\ E-mail: fabio_rpb@yahoo.com.br \\ Fernanda de Rezende Pinto \\ ORCID: https://orcid.org/0000-0002-0794-1984 \\ Universidade Federal de Pelotas, Brazil \\ E-mail: f_rezendevet@yahoo.com.br
}

\begin{abstract}
The article assesses the knowledge of professionals working in Basic Health Units (UBS) in rural areas about diseases transmitted by water and food. The work was carried out in partnership with the Environmental Surveillance sector of the Municipal Health Department of Pelotas and covered UBS in the rural area of the municipality of Pelotas, RS. Two questionnaires were applied to workers at ten UBS. Most of the participants, in the first (73.3\%) and in the second questionnaire (79.5\%), had not received training on the topics covered, however, they had some knowledge about water and foodborne diseases. Health professionals with a high level of education should have access to basic health and sanitation information. The development of a continuing education program on water quality and foodborne diseases would make these professionals more trained and safer to adequately guide the community about the risks and prevention of DTAs.
\end{abstract}

Keywords: Health education; Community health workers; Public health; Rural areas.

\section{Resumo}

O artigo avalia o conhecimento dos profissionais integrantes das Unidades Básicas de Saúde (UBS) da zona rural sobre doenças transmitidas pela água e alimentos. $\mathrm{O}$ trabalho foi realizado em parceria com o setor de Vigilância Ambiental da Secretaria Municipal de Saúde de Pelotas e abrangeu UBS da zona rural do município de Pelotas, RS. 
Foram aplicados dois questionários aos trabalhadores de dez UBS. A maioria dos participantes, no primeiro (73,3\%) e no segundo questionário (79,5\%), não havia recebido capacitações sobre os temas abordados, porém, possuía algum conhecimento em relação às doenças de transmissão hídrica e alimentar. Profissionais de saúde com grau de instrução médio devem ter acesso a informações básicas de saúde e saneamento. A elaboração de um programa de educação continuada sobre qualidade da água e doenças transmitidas por alimentos tornaria estes profissionais mais capacitados e mais seguros para orientar a comunidade adequadamente sobre os riscos e prevenção de DTAs.

Palavras-chave: Educação em saúde; Agentes comunitários de saúde; Saúde pública; Zona rural.

\begin{abstract}
El artículo evalúa los conocimientos de los profesionales que laboran en las Unidades Básicas de Salud (UBS) del medio rural sobre las enfermedades transmitidas por el agua y los alimentos. El trabajo se llevó a cabo en alianza con el sector de Vigilancia Ambiental del Departamento Municipal de Salud de Pelotas y cubrió la UBS en el área rural del municipio de Pelotas, RS. Se aplicaron dos cuestionarios a los trabajadores de diez UBS. La mayoría de los participantes, en el primero $(73,3 \%)$ y en el segundo cuestionario $(79,5 \%)$, no habían recibido capacitación en los temas tratados, sin embargo, tenían algún conocimiento sobre enfermedades de origen hídrico y alimentario. Los profesionales de la salud con un alto nivel de educación deben tener acceso a información básica sobre salud y saneamiento. El desarrollo de un programa de educación continua sobre la calidad del agua y las enfermedades transmitidas por los alimentos haría que estos profesionales estuvieran más capacitados y más seguros para orientar adecuadamente a la comunidad sobre los riesgos y la prevención de los DTA.
\end{abstract}

Palabras clave: Educación para la salud; Trabajadores comunitarios de la salud; Salud pública; Zonas rurales.

\title{
1. Introduction
}

The health problems resulting from the ingestion of contaminated food are known as Foodborne illnesses (DTAs). It is estimated that there are more than 250 types of foodborne illnesses, which cause various public health problems in addition to economic losses (Mendes et al., 2021; Melo et al., 2018). For this reason, it is important to be careful with foods of animal origin such as meat, milk and dairy products, as well as eggs and honey, because if these foods are stored or handled without proper hygienic-sanitary conditions, they can be used as substrates for multiplication of microorganisms, making them the source of the spread of numerous diseases (Cruz, 2018).

The consumption of contaminated water and food triggers serious public health problems worldwide. About $4.1 \%$ of diseases in the world are of diarrheal origin and are responsible for the death of 1.8 million people each year (OPAS - 2019). Health professionals must be aware of these diseases and guide the population about the risks of consuming water without prior treatment, food of unknown origin or doubtful origin, in addition to encouraging prevention and control practices (Brasil, 2012).

The Family Health Strategy (FHS) is a model that aims to organize primary care in Brazil and is considered a strategy for expansion, qualification and strengthening of primary care, benefiting the reorientation of the work process (Brasil, 2017).

In Brazil, Primary Health Care should preferably be the patient's gateway to the Unified Health System (SUS) and its principles are accessibility, comprehensiveness and universality (Brasil, 2017). However, in order to establish a model based on these principles and meet the demand of users, it is of paramount importance, in addition to having a qualified team, having resources that enable continuous education and performance evaluation of these teams (Abreu et al., 2018).

The composition of the FHS is multi-professional and is responsible for monitoring a certain number of families residing in a geographically delimited area (Speroni et al., 2016). These teams develop preventive health actions and encourage community participation, thus ensuring a process of education and health intervention with the objective of changing the traditional view of care focused on the health-disease process. (Paula et al., 2015).

This study aimed to assess the knowledge of FHS professionals about diseases transmitted by water and food and about the management of water supply sources. 


\section{Material and Methods}

This work was carried out in partnership with the Environmental Surveillance sector of the Municipal Health Department of Pelotas in ten Basic Health Units (BHU) in the rural area of Pelotas, RS. The rural area of Pelotas is composed of 12 BHU distributed in different regions, of which ten are FHS and, therefore, have a multidisciplinary health team.

The work was approved by the Human Ethics Committee of the Federal University of Pelotas (CAAE 64157516.5.0000.5317), all participants signed a Free and Informed Commitment Term for the collection of personal information before completing the questionnaires.

Contact with the BHU was made by telephone, and the nurse responsible for the team indicated the most appropriate day for the visit. This professional was in charge of communicating the date to the other BHU members. Using the team meeting day was the way to facilitate employee adherence to the activity.

The selection of research participants in the two questionnaires was non-probabilistic for convenience, and all BHU members who were present at the time were invited to fill out a structured, individual, self-administered questionnaire.

In the months of October and November 2018, the questionnaire referring to waterborne diseases was applied, containing questions about the place of residence, the origin of the water used by this professional in his residence, the necessary care with the protection factors of wells, possible forms of contamination of water from wells and waterborne pathogens. A total of 75 professionals answered this questionnaire.

From March to May 2019, a questionnaire on food-borne diseases was applied, containing questions related to care with the origin of milk and meat, fate of slaughtered animal viscera and food-borne zoonoses, such as hydatid disease and botulism. This questionnaire was answered by 83 professionals.

Data were entered into the EpiData 3.1 program and then descriptive and inductive statistical analysis was performed using the SPSS 20.0 software. For all participants, sociodemographic characteristics related to sex, age (up to 40 years; more than 40 years), education (up to high school; more than high school), length of service (up to 5 years; more than 5 years) were obtained and if they had already participated in any training on the subject. These characteristics were used as independent variables in the study. To identify which of these characteristics were associated with the perception and attitude of health professionals towards foodborne illnesses, the chi-square test $(\chi 2)$ or Fischer's exact test was performed, the latter when less than five observations were observed in at least one quadrant of the test. A $5 \%$ confidence level $(p<0.05)$ was considered in all statistical analyzes performed.

\section{Results}

In the evaluation of the perception of water quality and waterborne diseases, 75 questionnaires were filled out. Of the total, $35(46.7 \%)$ of the participants were community health workers, nine (12\%) nursing professionals, four (5.3) nursing assistants, five (6.7\%) nursing assistants, four (5.3\%) physicians, five (6.7\%) dentists, four (5.3\%) oral health assistants, two (2.7) social workers and seven (9.3\%) other members and members of BHU. Most professionals were women, 62 (82.7\%) and $38(50.7 \%)$ of the interviewees had completed high school.

Of the total, $55(73.3 \%)$ responded that they had never received prior training on the topic addressed. Most (74.7\%) of the participants lived in rural areas, 35 (46.7\%) used well water for human consumption and 24 (32.0\%) used water without any type of treatment.

Regarding the protection factors of water wells, when participants were asked which factors they considered important in a well, $68(90.7 \%)$ answered the presence of a lid, $61(81.3 \%)$ the presence of a wall above the ground , 56 
(74.4\%) presence of sidewalk around the well, 48 (64.0\%) presence of protection such as a roof $63(84.0 \%)$ presence of screen or fencing against approaching animals, and regarding location of the well on the ground, more than half of respondents 53 $(70.7 \%)$ indicated that the well should be built in the lowest part of the land.

Regarding good practices with water for human consumption from a well, $52(69.3 \%)$ said that some type of treatment must be carried out before consumption, $8(10.7 \%)$ responded that well water can be consumed without prior treatment and 15 (20\%) did not answer the question. Regarding the need to be careful with water before consumption, 72 (97\%) participants answered that it is necessary to take this care, citing methods such as chlorination, filtration and boiling before use. When asked whether water transmits diseases, the majority, 65 (86.7\%), responded positively.

During the evaluations on the topic of foodborne illnesses, 83 questionnaires were answered, 40 (48.2\%) by community health workers, nine $(10.8 \%)$ by nurses, eight $(9.6 \%)$ by health assistants. nursing, four (4.8\%) by physicians, five $(6 \%)$ by dentists, four $(4.8 \%)$ by oral health assistants, one $(1.2 \%)$ by nursing technician, two $(2.4 \%)$ by social workers and 10 $(12 \%)$ by other BHU professionals, such as receptionist, sanitizer, among others. Of the participants, most were female, 71 $(85.5 \%)$ and $12(14.4 \%)$ male. The age of participants ranged from 21 to 70 years. The educational level of most participants was average $43(51.8 \%)$. Regarding having participated in any previous training on the subject, 66 (79.5\%) had never received training, against only 17 (20.5\%), who replied that they had received some similar training.

When asked about the habit of buying milk directly from the producer, 28 (33.7\%) said they had this habit and 55 (64.3\%) did not buy milk directly from the producer. In the present study, professionals who consume milk straight from the producer were asked whether they usually boil it before ingestion. The majority, 27 (96.4\%), responded positively and only one person $(3.6 \%)$ responded that it sometimes boils. It was asked whether people associated milk consumption with disease transmission and $67(80.7 \%)$ answered yes, but $16(19.2 \%)$ said they did not associate milk with disease transmission. Also in the questionnaire, it was asked whether the tuberculosis disease can be transmitted by animals and 51 (61.4\%) answered affirmatively, but $32(38.6 \%)$ denied it or answered not knowing.

Another question addressed was about the purchase of meat directly from the producer and $53(63.9 \%)$ answered that they do not usually buy meat directly from the producer and 30 (36.1\%) answered that they buy sometimes or always. About the practice of slaughtering animals for human consumption at home, 47 (56.6\%) answered negatively to the question, while $36(43.4 \%)$ stated that they carry out the practice. They were also asked about the habit of providing raw viscera to domestic animals such as dogs and cats, and $63(75.9 \%)$ said they did not have the habit and $20(24.1 \%)$ said they usually do this practice.

People were asked if the consumption of honey could cause problems for children under two years old and 33 (39.8\%) responded positively, $25(30.1 \%)$ responded that honey does not cause a problem and $25(30.1 \%)$ could not answer. Still, it was asked if people relate the consumption of honey to any disease and 42 (50.6\%) answered not, 35 (42.2\%) answered yes and 6 (7.2\%) were unable to answer.

In this study, the association between the age of 20 to 40 years and the practice of slaughtering animals and supplying raw viscera to the animals was observed. In contrast, people aged 41 to 60 years are associated with a lower chance (approximately $82 \%)$ of slaughtering animals at home $(\mathrm{p}<0.05)$ (Table 1). Furthermore, it was observed that the perception of health professionals about foodborne illnesses improved with the increase in the level of education $(\mathrm{p}<0.05)($ Table 2$)$.

There were no significant associated statistical associations $(\mathrm{p}>0.05)$ between the variables sex, training and length of service. 
Table 1 - Age-related attitudes of 83 professionals from 10 Basic Health Units in the rural area of Pelotas - Rio Grande do Sul, in relation to slaughter and supply of offal to domestic animals, 2017.

\begin{tabular}{|c|c|c|c|c|c|c|}
\hline $\begin{array}{c}\text { Independent } \\
\text { Variable }\end{array}$ & \multicolumn{3}{|c|}{ Question Performed } & P value & Odds Ratio & IC $(95 \%)$ \\
\hline \multirow{2}{*}{ Age } & \multicolumn{3}{|c|}{ Slaughter animals at home } & & & \\
\hline & No & Yes & Total & & & \\
\hline 20 a 40 & 12 & 22 & $34(64,7 \%)$ & 0,001 & 0,218 & $0,085-0,557$ \\
\hline 41 a 60 & 35 & 14 & $49(28,7 \%)$ & & & \\
\hline Total & 47 & 36 & 83 & & & \\
\hline \multirow[t]{2}{*}{ Age } & \multicolumn{3}{|c|}{$\begin{array}{c}\text { Provides raw viscera to the house } \\
\text { animals }\end{array}$} & & & \\
\hline & No & Yes & Total & & & \\
\hline 20 a 40 & 21 & 13 & $34(38,2 \%)$ & 0,01 & 0,268 & $0,93-0,775$ \\
\hline 41 a 60 & 42 & 7 & $49(14,3 \%)$ & & & \\
\hline Total & 63 & 20 & 83 & & & \\
\hline
\end{tabular}

Source: Authors.

Table 2 - Factors associated with the education of 83 professionals from 10 BHU in the rural area of Pelotas, RS, in relation to risk factors for the transmission of foodborne illnesses.

\begin{tabular}{|c|c|c|c|c|c|c|}
\hline Independent Variable & \multicolumn{3}{|c|}{ Question Performed } & P Value & Odds Rattio & IC $(95 \%)$ \\
\hline \multirow{2}{*}{ Schooling } & \multicolumn{3}{|c|}{ Buy meat directly from the producer } & \multirow{5}{*}{0,006} & \multirow{5}{*}{0,241} & \multirow{5}{*}{$0,085-0,684$} \\
\hline & No & Yes & Total & & & \\
\hline Up to high school & 26 & 24 & $50(48,0 \%)$ & & & \\
\hline Higher than high school & 27 & 6 & $33(18,2 \%)$ & & & \\
\hline Total & 53 & 30 & 83 & & & \\
\hline \multirow[t]{2}{*}{ Schooling } & \multicolumn{3}{|c|}{$\begin{array}{l}\text { Tuberculosis can be transmitted by } \\
\text { animals }\end{array}$} & \multirow{5}{*}{0,008} & \multirow{5}{*}{3,714} & \multirow{5}{*}{$1,364-10,116$} \\
\hline & No & Yes & Total & & & \\
\hline Up to high school & 25 & 25 & $50(50 \%)$ & & & \\
\hline Higher than high school & 7 & 26 & $33(78,8 \%)$ & & & \\
\hline Total & 32 & 51 & 83 & & & \\
\hline \multirow[t]{2}{*}{ Schooling } & \multicolumn{3}{|c|}{ Honey can pose risk to children } & \multirow{5}{*}{0,003} & \multirow{5}{*}{4,500} & \multirow{5}{*}{$1,584-12,782$} \\
\hline & No & Yes & Total & & & \\
\hline Up to high school & 25 & 25 & $50(50,0 \%)$ & & & \\
\hline Higher than high school & 6 & 27 & $33(81,8 \%)$ & & & \\
\hline Total & 31 & 52 & 83 & & & \\
\hline \multirow[t]{2}{*}{ Schooling } & \multicolumn{3}{|c|}{$\begin{array}{l}\text { Associates honey consumption with any } \\
\text { disease }\end{array}$} & \multirow{5}{*}{0,001} & \multirow{5}{*}{4,500} & \multirow{5}{*}{$1,757-11,523$} \\
\hline & No & Yes & Total & & & \\
\hline Up to high school & 36 & 14 & $50(28 \%)$ & & & \\
\hline Higher than high school & 12 & 21 & $33(63,6 \%)$ & & & \\
\hline Total & 48 & 35 & 83 & & & \\
\hline \multirow[t]{2}{*}{ Schooling } & \multicolumn{3}{|c|}{$\begin{array}{l}\text { Associates the consumption of homemade } \\
\text { preserves }\end{array}$} & \multirow{5}{*}{0,003} & \multirow{5}{*}{6,129} & \multirow{5}{*}{$1,642-22,876$} \\
\hline & No & Yes & Total & & & \\
\hline Up to high school & 19 & 31 & $50(62 \%)$ & & & \\
\hline Higher than high school & 3 & 30 & $33(90,9 \%)$ & & & \\
\hline Total & 22 & 61 & 83 & & & \\
\hline
\end{tabular}




\section{Discussion}

Source: Authors.

The results showed a high percentage of people who consume water directly from wells and without prior treatment. A study in Viçosa, Minas Gerais, identified that $98.5 \%$ of rural residents used well water, without prior treatment for consumption (Oliveira et al., 2017).

It was found that, in general, people recognize that contamination of well water can interfere with the health of the population, causing various waterborne diseases.

The lack of knowledge about milk-transmitted diseases in this work is similar to that described by Vidal-Martins et al., (2013) where when questioning milk consumers about the transmission of diseases, 65.9\% answered not knowing or denying that the milk can transmit diseases. This data reveals that the lack of knowledge about the transmission of diseases transmitted by dairy products is still great, a worrying fact, knowing that Mycobacterium bovis, the main causative agent of bovine tuberculosis, can be eliminated through milk, and transmitted to people when they consume a product not inspected and without prior heat treatment of milk and its derivatives (Rocha, 2013).

The results also indicate that there is a high percentage of health professionals who are unaware of hydatid disease, a zoonotic disease that still occurs today due to the fact that dogs have access to raw viscera of animals that have the parasite. Human cystic echinococcosis is considered one of the most important zoonotic diseases worldwide. (Rodrigues et al., 2016).

Honey is a food product with high energy value, is widely used for therapeutic purposes and is also offered to children, but it is a food that may be contaminated with Clostridium botulinum spores and, due to this contamination, there is a warning that parents and family members do not provide honey to children under two years of age, in order to avoid the risk of developing infant botulism (Paulino, 2009; Marcucci, 2009). Thus, it is important that health professionals know the risks related to this food and pass this information on to the families served.

Statistical analysis showed that younger health professionals have the habit of slaughtering animals at home and providing raw viscera to domestic animals. It was also observed that individuals over 40 years of age and with a higher level of education do not have the habit of buying meat directly from the producer and are more likely to have already heard of foodborne illnesses. These data indicate that education and age contributed to a better perception of professionals about foodborne illnesses, perhaps because they have more access to information about caring for the origin and health of these foods, however, no articles were found in the literature to compare the findings found in this research.

These results demonstrate the importance of providing training to professionals who are entering the health service, so that the entire team will interact, learn and improve the quality of care and return to the population (Santili et al., 2016; Tavares et al., 2016). However, most professionals who join the FHS program teams do not receive training on important topics, such as prevention of diseases transmitted by water and food and food hygiene, thus, it is difficult for them to identify the presence of diseases related to food in the population served (Barreto et al., 2019).

Thus, training professionals involved in primary health care, as a tool for health promotion through preventive actions and guidance to the population, can be the way to reduce the incidence of foodborne outbreaks. (Costa et al., 2018). Promoting educational practices, conversation circles or case discussions in the work environment is a way to share knowledge, both in terms of education and life, and promote the integration of the team, thus facilitating the analysis of the population's health problems and your surroundings (Santo et al., 2017).

More qualified professionals tend to be more confident, have greater self-esteem and autonomy, facilitating and qualifying the progress of work. That is why it is important to encourage educational practices during the training of these professionals. (Oliveira et al., 2020; Morais et al., 2020), as contact with reality encourages the search for specific solutions, 
generates greater interaction with the community and favors the creation of a link between the health unit and the population served (de Melo et al., 2020; Barreto et al., 2019).

The advancement of technology tends to facilitate the development of tools that promote continuing education (Celestino et al., 2020). A continuing education program can be done at a distance with the help of didactic and technological resources, such as internet channels. Another alternative is to establish partnerships with public or private educational institutions and hold lectures or workshops within the work units, which facilitates the adhesion of all professionals in the place, promotes training, encourages the exchange of experiences and brings team members together (Celestino et al., 2020; Morais et al., 2020).

Health education is a tool to be used to reduce problems related to public health. To establish a healthy relationship between man and animal, it is necessary to educate people, not only with advertising and mass dissemination in the media, but with systematic health education programs, properly directed at the target audience (Oliveira et al., 2020).

\section{Conclusion}

Given the above, it was concluded that health professionals at BHU in the rural area of Pelotas have some education about water-borne diseases and the necessary care with protective factors, as well as in relation to foodborne illnesses. However, they still lack relevant information regarding these diseases and their form of prevention. That is why it is important to carry out educational campaigns and training lectures for these professionals in order to raise awareness and provide guidance on the severity, forms of transmission and prevention of these diseases, this will facilitate the dissemination of correct knowledge by them to other members of the community answered. Training is a way of valuing the professional, making him an opinion maker, capable of winning the trust of the community he serves. Health professionals are key players in social changes that reflect on the health of the population served and are added to the work of the family health team.

\section{References}

Abreu, D., Araújo, L., Reis, C., Lima, Â., Santos, A., Jorge, A. O., Fonseca Sobrinho, D., \& Machado, A. (2018). Service users' perception about healthcare provided by teams participating in the National Program for Primary Care Access and Quality Improvement in Brazil. Percepção dos usuários sobre o cuidado prestado por equipes participantes do Programa Nacional de Melhoria do Acesso e da Qualidade da Atenção Básica no Brasil. Epidemiologia e servicos de saude: revista do Sistema Unico de Saude do Brasil, 27(3), e2017111. https://doi.org/10.5123/S1679-49742018000300002

Barreto, Ana Cristina Oliveira et al. (2019), Perception of the Primary Care multiprofessional team on health education. Revista Brasileira de Enfermagem [online]. 72(1) 266-273. <https://doi.org/10.1590/0034-7167-2017-0702>. https://doi.org/10.1590/0034-7167-2017-0702.

Brasil. Ministério da Saúde. Portaria n 2.436 de 21 de setembro de 2017. Aprova a Política Nacional de Atenção Básica. Diário Oficial da União, Brasília, DF, 22 out. 2020. <https://bvsms.saude.gov.br/bvs/saudelegis/gm/2011/prt2488_21_10_2011.html>.

Brasil. Ministério da Saúde. Saúde da criança: crescimento e desenvolvimento. Secretaria de Atenção à Saúde. Departamento de Atenção Básica. Cadernos de Atenção Básica, Brasília DF, n. 33, 2012. 〈https://bvsms.saude.gov.br/bvs/publicacoes/saude_crianca_crescimento_desenvolvimento.pdf>.

Brasil. Ministério da Saúde. Secretária de Atenção à Saúde. PNAB - Política Nacional de Atenção Básica. Departamento de Atenção Básica, Brasília, DF, 2017. <http://189.28.128.100/dab/docs/publicacoes/geral/pnab.pdf>

Celestino L. C., Leal L. A., Silva B. R. da, Silva S. H., Ribeiro B. M. dos S. S., de Marchi Barcelos DalryR. de C., \& HenriquesS. H. (2020). Capacitação profissional na Estratégia Saúde da Família: percepção dos enfermeiros. Revista Eletrônica Acervo Saúde, 12(9), e3751. https://doi.org/10.25248/reas.e3751.2020

Costa, M. V., da et al. (2018), A Educação e o trabalho interprofissional alinhados ao compromisso histórico de fortalecimento e consolidação do Sistema Único de Saúde (SUS). Interface - Comunicação, Saúde, Educação 22(2), 1507-1510. <https://doi.org/10.1590/1807-57622018.0636>. https://doi.org/10.1590/1807-57622018.0636.

Cruz, F. (2018). Doenças Transmitidas por Alimentos (DTA) - Causas, Sintomas e Como Evitar. Baktron, https://baktron.com.br/doencas-transmitidas-poralimentosdta-causa-sintomas-e-como-evitar/;

de Melo A. R. F. F., dos Santos C. S., e Lima T. R. de M., \& Rego filho J. F. do. (2020). Concepção dos enfermeiros na estratégia saúde da família referente a uma capacitação problematizadora em um município do estado Pernambuco. Revista Eletrônica Acervo Saúde, (44), e2986. https://doi.org/10.25248/reas.e2986.2020 
Melo, E. S., Amorim, W. R., Pinheiro, R. E. E., Corrêa, P. G. N.; Carvalho, S. M. R.; Santos, A. R. S. S.; Barros, D. S.; Oliveira, E. T. A. C.; Mendes, C. A.; \& Sousa, F. V. (2018). Doenças transmitidas por alimentos e principais agentes bacterianos envolvidos em surtos no Brasil. Revista Pubvet, 131-131. https://doi.org/10.31533/pubvet.v12n10a191.1-9

Mendes, A. M., \& Ribeiro, L. F. (2021). O controle microbiológico da qualidade de alimentos. Revista Pubvet 162 https://doi.org/10.31533/pubvet.v15n02a744.1-10

Mendonça, F. T. N. F., de et al. (2017), Health education with older adults: action research with primary care professionals. Revista Brasileira de Enfermagem 70(4), 792-799. https://doi.org/10.1590/0034-7167-2016-0349.

Morais, S. R., Freitas, V. J. G., Alves, L. S. B., Nóbrega, C. B. C., Costa, L. E. D., \& Feitosa, F. S. Q. (2020). The role of university extension in the training teachers as multipliers of oral health. Research, Society and Development, 9(8), e315985321. https://doi.org/10.33448/rsd-v9i8.5321

Oliveira dos Santos, A., Cristian Do Amaral, P., Fernandes de Moura Pires, B., Machado Rocha, G., \& Cabral Silva, H. (2020). Percepções de estudantes de medicina e profissionais de saúde sobre a capacitação de equipes da atenção primária à saúde no enfrentamento da epidemia da COVID-19. Revista Brasileira De Extensão Universitária, 11(2), 227-236. https://doi.org/10.36661/2358-0399.2020v11i2.11528

Oliveira, Julimara de Souza Costa et al. Soluções individuais de abastecimento de água para consumo humano: questões para a vigilância em saúde ambiental. Cadernos Saúde Coletiva 25(2), 217-224. 〈https://doi.org/10.1590/1414-462X201700020371〉. https://doi.org/10.1590/1414-462X201700020371.

OPAS - Organização Pan-Americana da Saúde. Segurança dos alimentos é de responsabilidade de todos, 2019. OPAS - Organização Pan-Americana da Saúde. <https://www.paho.org/bra/index.php?option=com_content\&view=article\&id=5960:seguranca-dos-alimentos-e-responsabilidade-detodos\&Itemid $=875>$.

Paula, R. A. O.; Faria, T.; Germano, J. L.; Oliver, J. C.; \& Veiga, S. M. O. M. Conhecimento Dos Agentes Comunitários De Saúde Sobre Segurança Alimentar E Intervenção. Revista de APS - Atenção Primária à Saúde, 18(1), 16-21 <https://periodicos.ufjf.br/index.php/aps/article/view/15461〉. Acesso em: $18 / 06 / 2020$.

Paulinho, R. S.; \& Marcucci, M. C. (2009). <Análises físico químicas de méis do Ceará. Revista Pesquisa e Inovação Farmacêutica, 1(1), 63-78 https://revista.pgsskroton.com/index.php/RPInF/article/view/171>.

Rocha, B. B. (2013). Ocorrência de Mycobacterium bovis em queijos coalho artesanais e fatores associados ao consumo de leite e derivados lácteos informais. Dissertação (Programa de Pós-Graduação em Medicina Veterinária) - Universidade Federal de Viçosa.

Rodrigues, D. A. S.; Alencar, D. F.; \& Medeiros, B. L. N. (2016). Aspectos epidemiológicos, clínicos e patológicos da hidatidose. Revista Pubvet, 10(1), 8790, <https://www.pubvet.com.br/uploads/75e3eb4233f92d9c5a71a5ea773cc4b9.pdf>.

Santili, P. G. J., Tonhom, S. F. da R., \& Marin, M. J. S. (2017). Educação em saúde: algumas reflexões sobre sua implementação pelas equipes da estratégia saúde da família. Revista Brasileira Em Promoção Da Saúde, 29, 102-110. https://doi.org/10.5020/18061230.2016.sup.p102

Santos, A., Fonseca, D., Sobrinho, Araujo, L. L., Procópio, C., Lopes, É., Lima, A., Reis, C., Abreu, D., Jorge, A. O., \& Matta-Machado, A. T. (2017). Incorporação de Tecnologias de Informação e Comunicação e qualidade na atenção básica em saúde no Brasil [Incorporation of Information and Communication Technologies and quality of primary healthcare in Brazil]. Cadernos de saude publica, 33(5), e00172815. https://doi.org/10.1590/0102$311 \times 00172815$

Speroni, K. S., et al. (2016). Percepções dos agentes comunitários de saúde: contribuições para a gestão em saúde. Revista Cuidarte, 7 (2), $1325-1337$. https://doi.org/10.15649/cuidarte.v7i2.338

Tavares, M. de F. L., et al. (2016) A promoção da saúde no ensino profissional: desafios na Saúde e a necessidade de alcançar outros setores. Ciência \& Saúde Coletiva 21(6), 1799-1808. https://doi.org/10.1590/1413-81232015216.07622016.

Vidal-Martins, A., Bürger, K., Gonçalves, A., Grisólio, A., Aguilar, C., \& Rossi, G. (2013). Avaliação do consumo de leite e produtos lácteos informais e do conhecimento da população sobre os seus agravos à saúde pública, em um município do Estado de São Paulo, Brasil. Boletim De Indústria Animal, 70(3), 221-227. https://doi.org/10.17523/bia.v70n3p221 